\title{
Optimization of the Effect of Accelerated Weathering Conditions on Wood Surfaces via the Taguchi Method
}

\begin{abstract}
Rifat Kurt * and Ahmet Can
This study investigated the effect of accelerated weathering conditions on total color changes on Scots pine (Pinus sylvestris L.) and poplar (Populus $x$ euroamericana) wood surfaces using the Taguchi method. The experiments, based on the $L_{18}$ orthogonal array, were conducted separately for both tree species. The radial and tangential surfaces of wood specimens were subjected to an accelerated weathering process using $340 \mathrm{~nm}$ ultraviolet (UV) lamps and temperature conditions of $50^{\circ} \mathrm{C}$. The factors for the minimum color change were determined via the signalto-noise $(S / N)$ ratios of the four parameters thought to be effective on color change. These parameters were cutting direction (two levels), UVirradiance, conditioning, and water (three levels each). The most important factor affecting the color change was then determined by analysis of variance (ANOVA) testing. The results showed that the maximum UVirradiance $\left(\mathrm{W} / \mathrm{m}^{2}\right)$ had the largest effect on the total color change, while the cutting direction (radial and tangential) had the smallest effect. The factors that affected the total color change of the poplar and Scots pine wood specimens were the same. However, the analysis revealed that different application times had varying effects on the color change.
\end{abstract}

Keywords: Accelerated weathering; Color change; Optimization; Taguchi method; Wood

Contact information: Department of Forest Industrial Engineering, Faculty of Forestry, Bartin University, Bartin, Turkey; *Corresponding author: rkurt@bartin.edu.tr

\section{INTRODUCTION}

Wood is one of the most abundant materials in nature, and it possesses superior properties compared with other building materials. Wood is a renewable material with low density, low heat conductivity, high mechanical strength, easy processability, and good aesthetic appearance. When wood is exposed to weathering without any protective treatment, it degrades under ultraviolet (UV) light. This degradation can cause leaching, hydrolysis and water swelling, discoloration, and decay by microorganisms. Ultimately, chemical changes in wood, changes in color, microscopic changes, physical changes, and changes caused by biological factors are developed as a time-specific effect.

There can be significant changes in the surface of the wood as a result of UVradiation, humidity (rain, snow, moisture, and dew), mechanical effects (wind and dirt), temperature, and atmospheric factors $\left(\mathrm{O}_{2}, \mathrm{SO}_{2}\right.$, and pollutant gases). The most important among these factors are light, moisture, and oxygen. The UV-radiation of the sun change the chemical components of the lignin on the wood surface and initiate photo degradation. The moisture in the wood increases free radical formation by expanding the gaps in the substructure of the wood, thus allowing deeper penetration of the light. Temperature is another factor in the outdoor weathering that affects wood properties. However, the temperature does not have as significant an effect on wood specimens as water and UV light do (Feist and Hon 1984; Feist 1990; Temiz 2005; Kropat et al. 2020). 
Wood functions at its maximum strength in the tangential direction (parallel to the annual rings), slightly less in the radial direction (perpendicular to the annual rings) and very little in the longitudinal direction against weathering. Over time, physical changes in the surface of the wood due to moisture content, such as shrinkage and expansion, can cause defects such as cracking and detachment. On tangential surfaces exposed to weathering, lengthwise cracks occur in earlywood, whereas on radial surfaces in latewood, cracks form in the annual ring boundary. These cracks allow water and UV-radiation to penetrate the depths of the wood. Therefore, more degradation occurs from the wood surface (Temiz 2005; Özgenç 2014; Can and Sivrikaya 2019; Kropat et al. 2020). Because testing of weathering requires a long period of time, accelerated weathering tests are carried out in laboratory environments (Temiz et al. 2005, 2007; Way et al. 2018; Tian et al. 2019). Using this method, the results are obtained in less time.

When exposed to outdoor conditions, wood surfaces rapidly change color. The wood surface at first turns yellow and then turns brown as time passes. It is sometimes possible to detect these color changes with the naked eye, but this is not significant. A significant expression of this change is possible by measuring the $L^{*}, a^{*}$, and $b^{*}$ values using a spectrophotometer. The CIE LAB colourimetric system, which is described by three parameters: $L^{*}$ (lightness that defines the black-white axis), $a^{*}$ (represents the redgreen axis), and $b^{*}$ (represents the yellow-blue axis), has been commonly used to evaluate HT induced wood discolouration (Temiz 2005; Temiz et al. 2007; Can 2018; Aydemir et al. 2019). The most important value for detecting the color difference between test and control samples is the $\Delta E^{*}$. It alone expresses the "total color difference" between two specimens. The greater the $\Delta E^{*}$, the greater the difference between the colors compared (Can 2018).

This study used the Taguchi method to examine the accelerated weathering test factors of UV, water, and conditioning (at $50{ }^{\circ} \mathrm{C}$ ) to determine which factors had the largest effect on the total color change of wood. In addition, the effects of the cutting direction of the wood surface and the wood species on the total color change were also investigated.

\section{EXPERIMENTAL}

\section{Materials}

Scots pine (Pinus sylvestris L.) (oven-dry density of $0.49 \mathrm{~g} / \mathrm{cm}^{3}$ ) and poplar (Populus $x$ euroamericana) (oven-dry density of $0.28 \mathrm{~g} / \mathrm{cm}^{3}$ ) timber were purchased from the Kartal Ahşap Company in Bartin, Turkey. The wood was cut into specimens with dimensions of $5 \mathrm{~cm} \times 7.5 \mathrm{~cm} \times 15 \mathrm{~cm}$. The specimens were cut to give tangential and radial surfaces. The specimens were free of knots and they showed no visible evidence of infection by mold or fungi. Prior to weathering, the wood specimens were put in the conditioning room at $65 \%$ relative humidity $(\mathrm{RH})$ and $22{ }^{\circ} \mathrm{C}$ until a constant weight was achieved (ISO 554, 2016).

\section{Methods}

Accelerated weathering test $(Q U V)$

The accelerated weathering test was carried out according to the ASTM standard G154-16 (2016). However, different parameters were applied to determine the effect of different weathering factors on the total color change. Table 1 outlines the parameters that 
were applied in the accelerated weathering test. The applied UV process used a $340 \mathrm{~nm}$ lamp and the average temperature in the chamber was set to $50{ }^{\circ} \mathrm{C}$. Four replicate specimens of each variation were exposed to the accelerated weathering. The UV treatment was applied for a total of $24 \mathrm{~h}$. After every $2 \mathrm{~h}$ of UV treatment, water (for 15, 30, and 45 min) and conditioning (for 2, 4, and $6 \mathrm{~h}$ ) treatments were applied. For example, after $2 \mathrm{~h}$ $0.5 \mathrm{~W} / \mathrm{m}^{2} \mathrm{UV}$ application, water spray was applied for $45 \mathrm{~min}$. After the water spray treatment was applied, the sample was conditioned for $6 \mathrm{~h}$ at $50{ }^{\circ} \mathrm{C}$ in the accelerated weathering cycle. After repeating accelerated weathering test 12 times, the accelerated weathering of the group was completed.

\section{Total color change measurement}

The color measurement was performed with a Konica Minolta spectrophotometer (Osaka, Japan) by measuring the $L^{*}, a^{*}$, and $b^{*}$ values on the specimens. For each sample, four color measurements were made in randomly selected zones, according to the ISO standard 7724-2 (1984). The changes in the color coordinates $\left(\Delta L^{*}, \Delta a^{*}\right.$, and $\left.\Delta b^{*}\right)$ were determined by the difference between the final and initial values. The total color change $\left(\Delta E^{*}\right)$ was calculated according to Eq. 1 ,

$$
\left(\Delta E^{*}\right)=\left[\left(\Delta a^{*}\right)^{2}+\left(\Delta b^{*}\right)^{2}+\left(\Delta L^{*}\right)^{2}\right]^{1 / 2}
$$

\section{Taguchi method}

The Taguchi method is used extensively for industrial and engineering problems due to its wide range of applications (Chamoli 2015; Günay et al. 2011). Taguchi method of creating a statistical design by using an orthogonal array also offers an opportunity to reduce the number of experiments (Bose et al. 2013; Sarikaya and Güllü 2015; Balki et al. 2016). Thus, the design parameters can be optimized, and the overall experimental costs can be significantly reduced (Joshaghani et al. 2015). Taguchi has recommended three stage processes to achieve the desired product quality by design: system design, parameter design, and tolerance design. The system design stage helps to identify the suitable working levels of the design parameters. The parameter design stage determines the factor levels that produce the best process performance. The tolerance design stage fine-tunes the results of the parameter design by tightening the tolerance of the factors with significant influence on the product (Apparao and Birru 2017).

The Taguchi technique computes a signal-to-noise $(\mathrm{S} / \mathrm{N})$ ratio based on experimental data (Kivak 2014). The $\mathrm{S} / \mathrm{N}$ ratio is defined as the desired signal ratio for the undesired random noise value and shows the quality characteristics of the experimental data (Kurt et al. 2009; Günay et al. 2011; Günay and Yücel 2013). A larger S/N ratio represents a better quality characteristic and the corresponding process parameters are incentive to the variation of environmental conditions and other noise factors (Chiang and Hsieh 2009). Depending on the particular characteristics of the design problem, different $\mathrm{S} / \mathrm{N}$ ratios may be applicable, including "lower-is-better" (LB), "nominal-is-best" (NB), or "higher-is-better" (HB) (Chen et al. 2007). The goal of this study was to minimize the color change for Scots pine and poplar. Therefore, aiming to reach the minimum value the LB quality characteristic was used for all levels of process parameters, as shown in Eq. 2,

$$
S /_{N}=-10 \log \left[\frac{1}{n} \sum_{i=1}^{n} y_{i}^{2}\right]
$$

where, $n$ is the number of observations of the experiment and $y_{i}$ is the observed data at the $i^{\text {th }}$ experiment (Taguchi et al. 2005; Mandal et al. 2011; Kivak 2014). 


\section{Definition of factors and levels}

To identify the most important factors affecting the color change in Scots pine and poplar woods, factors affecting the color applied in this study are shown in Table 1.

Table 1. Color Change Parameters and Levels

\begin{tabular}{|c|l|c|c|c|}
\hline \multirow{2}{*}{ Codes } & \multicolumn{2}{|c|}{ Parameters } & \multicolumn{3}{|c|}{ Levels } \\
\cline { 3 - 5 } & & 1 & 2 & 3 \\
\hline A & Direction & Radial & Tangential & - \\
\hline B & UV-irradiance $\left(\mathrm{W} / \mathrm{m}^{2}\right)$ & 0.5 & 0.75 & 1.0 \\
\hline C & Conditioning $(\mathrm{h})$ & 2.0 & 4.0 & 6.0 \\
\hline D & Water $(\mathrm{min})$ & 15.0 & 30.0 & 45.0 \\
\hline
\end{tabular}

\section{Orthogonal array selection}

With the Taguchi method, it is possible to achieve results with a much smaller number of experimental studies using an orthogonal array table. The main feature of the orthogonal indices is that all the factors are included in the experiment with an equal number of trials. The orthogonal indices shown in the form of $L_{a}\left(b^{c}\right)$ are derived from the Latin square design, with " $L$ " representing the Latin square design. The " $a$ " refers to the number of experiments, the " $b$ " refers to the number of levels in each column, and the " $c$ " refers to the number of factors (Ross 1988; Mezarcioz and Ogulata 2010). In this study, the optimum measurement parameters affecting color change were two levels of direction and three levels each of wavelength, conditioning, and water. The $\mathrm{L}_{18}\left(2^{1} \times 3^{3}\right)$ array was chosen as the most suitable orthogonal sequence for these factors and levels. In order to reach the optimum solution under normal conditions, 54 experiments would have been required for each of the two tree species, while the ideal solution was reached with 18 experiments per species using the Taguchi experimental design. Table 2 shows the $\mathrm{L}_{18}$ mixed orthogonal array used for the experiments.

Table 2. Orthogonal Array of Taguchi $L_{18}\left(2^{1} \times 3^{3}\right)$

\begin{tabular}{|c|c|c|c|c|c|c|c|c|c|}
\hline \multirow{2}{*}{$\begin{array}{c}\text { Experiment } \\
\text { No. }\end{array}$} & \multicolumn{4}{|c|}{ Scots pine } & \multicolumn{5}{|c|}{ Poplar } \\
\cline { 2 - 9 } & $\begin{array}{c}\text { Factor } \\
\text { A }\end{array}$ & $\begin{array}{c}\text { Factor } \\
\text { B }\end{array}$ & $\begin{array}{c}\text { Factor } \\
\text { C }\end{array}$ & $\begin{array}{c}\text { Factor } \\
\text { D }\end{array}$ & $\begin{array}{c}\text { Factor } \\
\text { A }\end{array}$ & $\begin{array}{c}\text { Factor } \\
\text { B }\end{array}$ & $\begin{array}{c}\text { Factor } \\
\text { C }\end{array}$ & $\begin{array}{c}\text { Factor } \\
\text { D }\end{array}$ \\
\hline 1 & 1 & 1 & 1 & 1 & & 1 & 1 & 1 & 1 \\
\hline 2 & 1 & 1 & 2 & 2 & & 1 & 1 & 2 & 2 \\
\hline 3 & 1 & 1 & 3 & 3 & & 1 & 1 & 3 & 3 \\
\hline 4 & 1 & 2 & 1 & 1 & & 1 & 2 & 1 & 1 \\
\hline 5 & 1 & 2 & 2 & 2 & & 1 & 2 & 2 & 2 \\
\hline 6 & 1 & 2 & 3 & 3 & & 1 & 2 & 3 & 3 \\
\hline 7 & 1 & 3 & 1 & 2 & & 1 & 3 & 1 & 2 \\
\hline 8 & 1 & 3 & 2 & 3 & & 1 & 3 & 2 & 3 \\
\hline 9 & 1 & 3 & 3 & 1 & & 1 & 3 & 3 & 1 \\
\hline 10 & 2 & 1 & 1 & 3 & & 2 & 1 & 1 & 3 \\
\hline 11 & 2 & 1 & 2 & 1 & & 2 & 1 & 2 & 1 \\
\hline 12 & 2 & 1 & 3 & 2 & & 2 & 1 & 3 & 2 \\
\hline 13 & 2 & 2 & 1 & 2 & & 2 & 2 & 1 & 2 \\
\hline 14 & 2 & 2 & 2 & 3 & & 2 & 2 & 2 & 3 \\
\hline 15 & 2 & 2 & 3 & 1 & & 2 & 2 & 3 & 1 \\
\hline 16 & 2 & 3 & 1 & 3 & & 2 & 3 & 1 & 3 \\
\hline 17 & 2 & 3 & 2 & 1 & & 2 & 3 & 2 & 1 \\
\hline 18 & 2 & 3 & 3 & 2 & & 2 & 3 & 3 & 2 \\
\hline
\end{tabular}


Analysis of Variance (ANOVA)

Analysis of variance (ANOVA) is a statistical method used to determine the individual interactions of all the control factors in a test design (Kivak 2014). The ANOVA test the variables by mean squaring and estimate the experimental errors at specific levels (Naik and Reddy 2018). The ANOVA test was performed to determine the most important parameter that affected the color change. MINITAB 18 software package was used for all statistical analysis.

\section{RESULTS AND DISCUSSION}

\section{Color Changes}

Table 3 shows the color changes $\left(L^{*}, a^{*}, b^{*}\right)$ of wood before and after weathering. After the weathering process, the specimen surfaces were darker. The declining $L^{*}$ value is proof of this. The $L^{*}$ value is the parameter most affected by weathering conditions, especially UV and rainwater. Other color parameters are less affected by rainwater (Temiz et al. 2005).

Table 3. Colour Changes Before and After Weathering of Wood

\begin{tabular}{|c|c|c|c|c|c|c|}
\hline \multirow{2}{*}{ Wood surface } & \multicolumn{3}{|c|}{ Before weathering } & \multicolumn{3}{c|}{ After weathering } \\
\cline { 2 - 7 } & $L^{*}$ & $a^{*}$ & $b^{*}$ & $L^{*}$ & $a^{*}$ & $b^{*}$ \\
\hline Scots Pine & 79.64 & 6.52 & 24.75 & 71.67 & 11.97 & 35.95 \\
Radial & $(0.95)$ & $(0.57)$ & $(1.08)$ & $(1.63)$ & $(0.96)$ & $(1.33)$ \\
\hline Scots Pine & 81.99 & 5.65 & 28.59 & 74.24 & 10.58 & 39.85 \\
Tangential & $(2.52)$ & $(1.85)$ & $(3.63)$ & $(3.12)$ & $(1.54)$ & $(1.97)$ \\
\hline Poplar & 85.77 & 3.34 & 16.39 & 79.20 & 7.38 & 31.57 \\
Radial & $(1.15)$ & $(0.56)$ & $(0.62)$ & $(1.17)$ & $(0.76)$ & $(1.36)$ \\
\hline Poplar & 85.84 & 3.20 & 15.66 & 79.15 & 6.95 & 31.77 \\
Tangential & $(1.36)$ & $(0.55)$ & $(0.55)$ & $(1.42)$ & $(0.78)$ & $(1.59)$ \\
\hline
\end{tabular}

In parentheses: SD

Since the surface of the wood exposed to weathering becomes more fibrous (rough) and darker, the $\underline{L}^{*}$ value from the surface of the control specimens decreased. Moreover, polymerization of lignin on the exposed surface caused the surface to become darker. This situation is also supported by the literature studies (Temiz et al. 2005; Baysal et al. 2014; Turkoglu et al. 2015). Among the chromatic coordinates, the ( $\left.a^{*}\right)$ value representing the red-green coordinates and the $\left(b^{*}\right)$ value representing the blue and yellow coordinates increased with the weathering process.

\section{Analysis of the $\mathrm{S} / \mathrm{N}$ ratio and the Optimization of the Experimental Results}

Table 4 shows the experimental results of the $\mathrm{S} / \mathrm{N}$ ratio calculated for each experiment based on Eq. 2 (LB) according to the Taguchi experimental design $\mathrm{L}_{18}$ orthogonal index related to the color changes in Scots pine and poplar woods.

After the $\mathrm{S} / \mathrm{N}$ values were calculated according to the experimental results, the effect of each factor on all levels was investigated. For this, the average of the $\mathrm{S} / \mathrm{N}$ ratios given in Table 3 was calculated separately for each level of each factor. Table 4 shows the $\mathrm{S} / \mathrm{N}$ response table for color change in Scots pine and poplar wood. The $\mathrm{S} / \mathrm{N}$ values that are highest (here minimum absolute values) in the table in question indicate the best level of that parameter, i.e., the test result with the least amount of color change (Table 4). 
Table 4. Experimental Results and the S/N Ratio Values

\begin{tabular}{|c|c|c|c|c|c|c|c|c|}
\hline \multirow{2}{*}{$\begin{array}{c}\text { Experiment } \\
\text { No }\end{array}$} & \multicolumn{4}{|c|}{$\begin{array}{l}\text { Control Factors for Scots Pine } \\
(\mathrm{SP}) \text { and Poplar (P) }\end{array}$} & \multirow{2}{*}{$\begin{array}{l}\Delta E \\
(\mathrm{SP})\end{array}$} & \multirow{2}{*}{$\begin{array}{c}\mathrm{S} / \mathrm{N} \\
\text { Ratio for } \\
\mathrm{SP}\end{array}$} & \multirow{2}{*}{$\begin{array}{l}\Delta E \\
(\mathrm{P})\end{array}$} & \multirow{2}{*}{$\begin{array}{c}\mathrm{S} / \mathrm{N} \\
\text { Ratio for } \\
\mathrm{P}\end{array}$} \\
\hline & A & $B$ & $C$ & $\mathrm{D}$ & & & & \\
\hline 1 & Radial & 0.50 & 2 & 15 & 15.24 & $23 . \overline{6} 615$ & 20.65 & 26.2997 \\
\hline 2 & Radial & 0.50 & 4 & 30 & 14.77 & $\begin{array}{c}- \\
23.3862 \\
\end{array}$ & 15.58 & 23.8531 \\
\hline 3 & Radial & 0.50 & 6 & 45 & 15.17 & 23.6214 & 16.25 & 24.2161 \\
\hline 4 & Radial & 0.75 & 2 & 15 & 13.69 & $\begin{array}{c}- \\
22.7283 \\
\end{array}$ & 17.70 & 24.9611 \\
\hline 5 & Radial & 0.75 & 4 & 30 & 12.83 & $\begin{array}{c}- \\
22.1626\end{array}$ & 14.86 & $\begin{array}{c}- \\
23.4391\end{array}$ \\
\hline 6 & Radial & 0.75 & 6 & 45 & 14.02 & 22.9364 & 13.58 & $22 . \overline{-} \cdot 650$ \\
\hline 7 & Radial & 1.00 & 2 & 30 & 14.53 & $\begin{array}{c}- \\
23.2434 \\
\end{array}$ & 17.30 & $\begin{array}{c}- \\
24.7633 \\
\end{array}$ \\
\hline 8 & Radial & 1.00 & 4 & 45 & 15.70 & $\begin{array}{c}- \\
23.9161 \\
\end{array}$ & 19.08 & $\begin{array}{c}- \\
25.6123 \\
\end{array}$ \\
\hline 9 & Radial & 1.00 & 6 & 15 & 17.73 & 24.9762 & 18.84 & $\begin{array}{c}- \\
25.5003 \\
\end{array}$ \\
\hline 10 & Tangential & 0.50 & 2 & 45 & 18.40 & $\begin{array}{c}- \\
25.2974 \\
\end{array}$ & 17.96 & $\begin{array}{c}- \\
25.0862 \\
\end{array}$ \\
\hline 11 & Tangential & 0.50 & 4 & 15 & 19.96 & 26.0043 & 21.26 & 26.5526 \\
\hline 12 & Tangential & 0.50 & 6 & 30 & 16.62 & 24.4141 & 15.10 & 23.5794 \\
\hline 13 & Tangential & 0.75 & 2 & 30 & 10.68 & $\begin{array}{c}- \\
20.5751 \\
\end{array}$ & 17.66 & 24.9403 \\
\hline 14 & Tangential & 0.75 & 4 & 45 & 12.98 & $\begin{array}{c}- \\
22.2654 \\
\end{array}$ & 15.06 & $\begin{array}{c}- \\
23.5538 \\
\end{array}$ \\
\hline 15 & Tangential & 0.75 & 6 & 15 & 15.62 & $23 . \overline{8716}$ & 16.96 & $\begin{array}{c}- \\
24.5878 \\
\end{array}$ \\
\hline 16 & Tangential & 1.00 & 2 & 45 & 13.46 & 22.5837 & 20.04 & 26.0383 \\
\hline 17 & Tangential & 1.00 & 4 & 15 & 12.68 & 22.0601 & 17.03 & 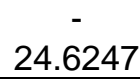 \\
\hline 18 & Tangential & 1.00 & 6 & 30 & 12.60 & $\begin{array}{c}- \\
22.0059 \\
\end{array}$ & 19.71 & 25.8925 \\
\hline
\end{tabular}

Table 5. S/N Response Table for Scots Pine and Poplar (LB)

\begin{tabular}{|c|c|c|c|c|c|c|c|c|c|}
\hline \multirow{2}{*}{ Level } & \multicolumn{4}{|c|}{ Scots pine } & \multicolumn{4}{|c|}{ Poplar } \\
\cline { 2 - 10 } & $\mathrm{A}$ & $\mathrm{B}$ & $\mathrm{C}$ & $\mathrm{D}$ & & $\mathrm{A}$ & $\mathrm{B}$ & $\mathrm{C}$ & $\mathrm{D}$ \\
\hline 1 & -23.40 & -24.40 & $\mathbf{- 2 3 . 0 1}$ & -23.88 & & $\mathbf{- 2 4 . 5 9}$ & -24.93 & -25.35 & -25.42 \\
\hline 2 & $\mathbf{- 2 3 . 2 3}$ & $\mathbf{- 2 2 . 4 2}$ & -23.30 & $\mathbf{- 2 2 . 6 3}$ & & -24.98 & $\mathbf{- 2 4 . 0 2}$ & -24.61 & $\mathbf{- 2 4 . 4 1}$ \\
\hline 3 & - & -23.13 & -23.64 & -23.44 & & & -25.41 & $\mathbf{- 2 4 . 4 1}$ & -24.53 \\
\hline Delta & 0.17 & 1.97 & 0.62 & 1.25 & & 0.39 & 1.38 & 0.94 & 1.01 \\
\hline Rank & 4 & 1 & 3 & 2 & & 4 & 1 & 3 & 2 \\
\hline
\end{tabular}

Figure 1 shows the graphical appearance of the optimum color change parameters and levels for Scots pine (Fig. 1a) and poplar (Fig. 1b) wood. The optimum parameters required to minimize the color change can easily be seen in the figure. According to Fig. 
1a, the minimum total color change in the Scots pine wood was obtained tangentially, at a UV-irradiance of $0.75 \mathrm{~W} / \mathrm{m}^{2}$, after $30 \mathrm{~min}$ of water spray and $2 \mathrm{~h}$ of conditioning. In the poplar specimens, it was obtained in the radial direction after a process of $0.75 \mathrm{~W} / \mathrm{m}^{2} \mathrm{UV}$ irradiance, $30 \mathrm{~min}$ of water spray and $6 \mathrm{~h}$ of conditioning.

a)

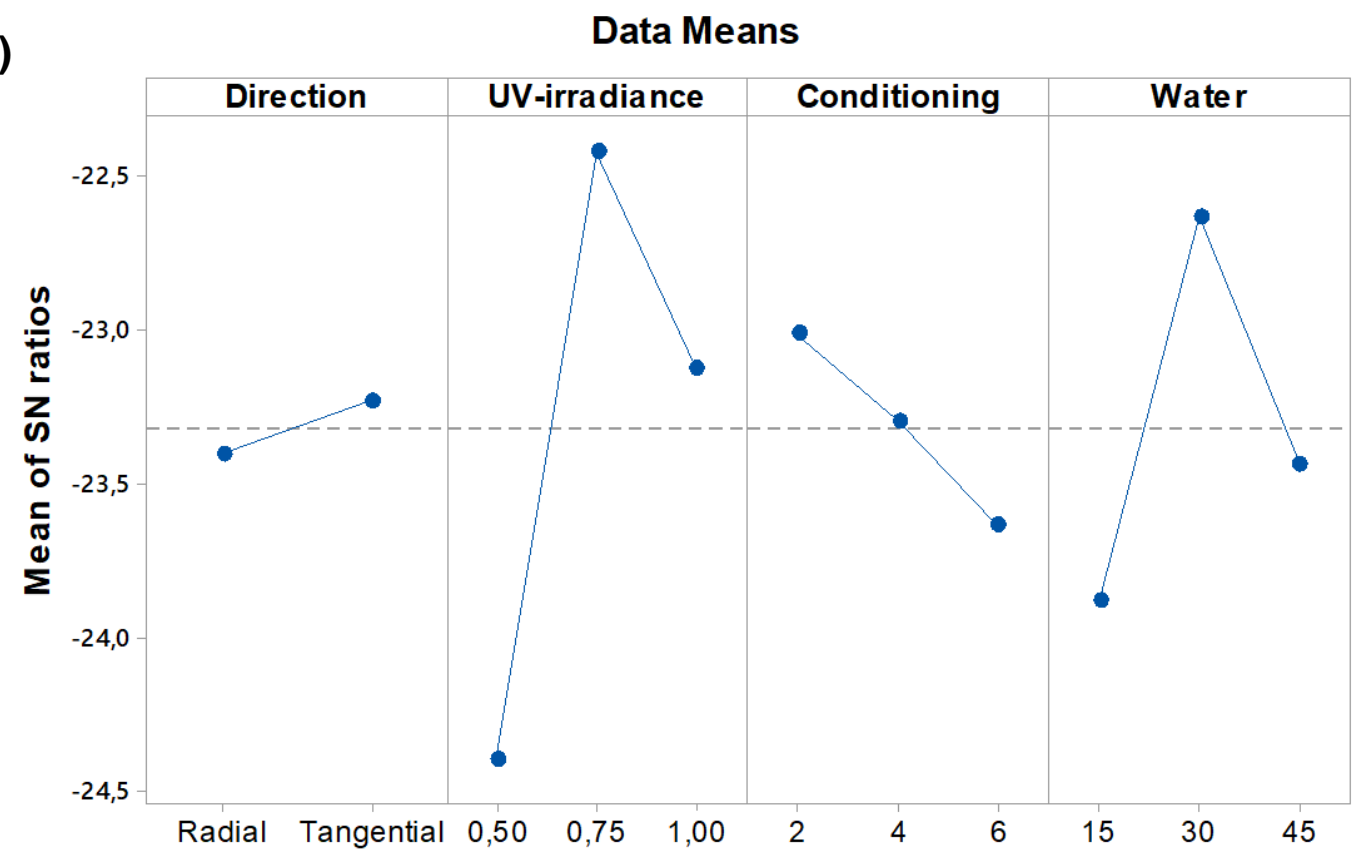

Signal-to-noise: Smaller is better

b)

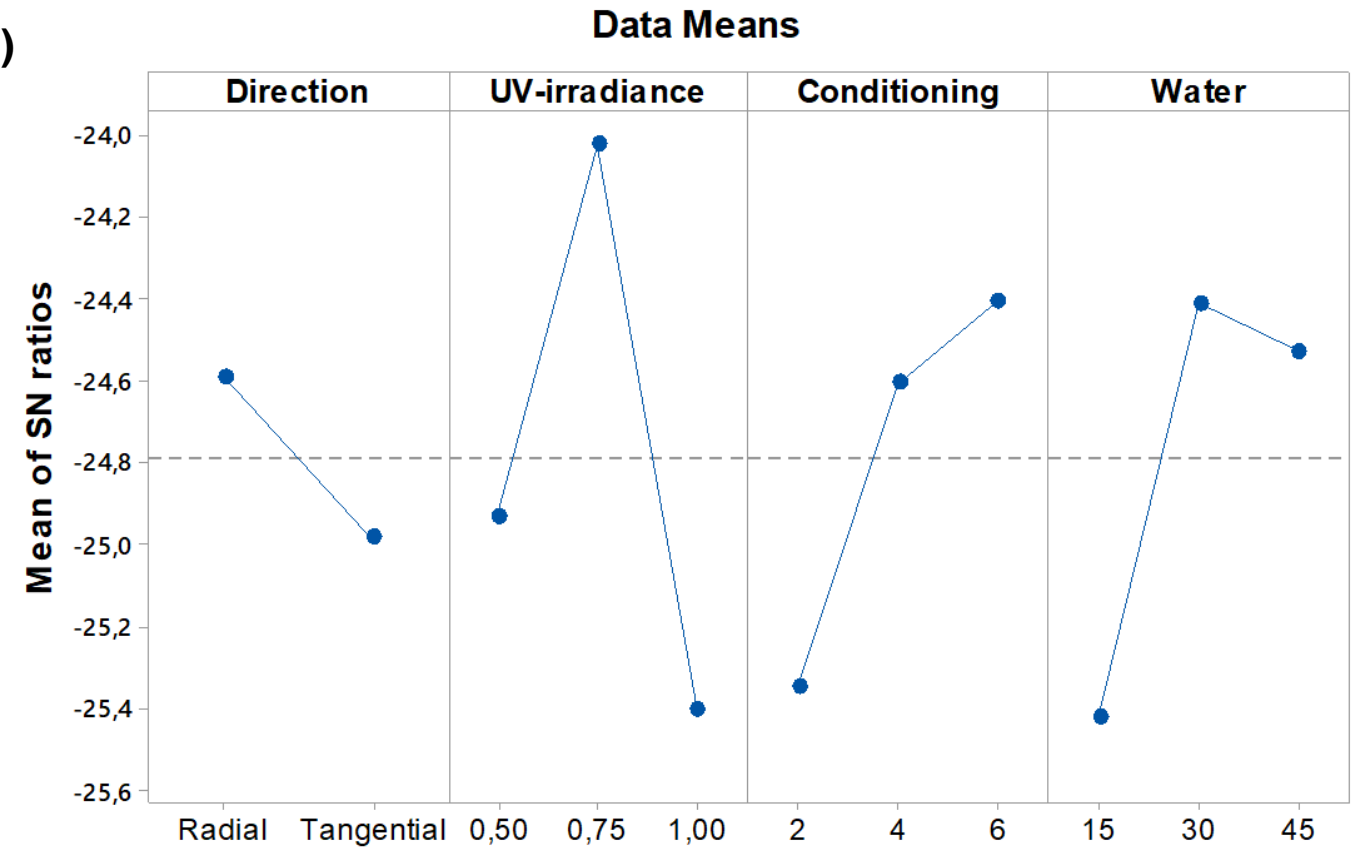

Signal-to-noise: Smaller is better

Fig. 1. The main effect plots for $\mathrm{S} / \mathrm{N}$ ratios for a) Scots pine and b) poplar 
The degradation that occurs on the wood surface due to external environmental conditions weakens the chemical bonds in the cell wall and causes microscopic and / or macroscopic stresses and cracks between and within cells. Wood with high density is more durable in outdoor conditions than wood with low density. In general, deciduous tree wood having high specific gravity degrades more slowly than coniferous wood. By the differences shown by the wood itself it exhibits different behaviors against outdoor environmental conditions. The walls of earlywood are eroded faster than those of latewood (Feist and Hon 1984; Williams et al. 2001).

Study has demonstrated that there are significant degradation differences on the radial and tangential surfaces of wood exposed to outdoor conditions. It has been observed that cracks are more numerous and deeper on tangential surfaces than on radial surfaces. Cracks on tangential wood surfaces occur especially between earlywood and latewood, whereas on radial surfaces, cracks form at the annual ring boundaries. The most prominent difference in erosion on tangential and radial surfaces was observed at the microscopic level in the cell membrane passages. Cell wall degradation occurs on both surfaces; but the separation in the middle lamella occurs on tangential surfaces, especially in latewood (Feist 1990).

\section{ANOVA Results}

The ANOVA results demonstrate that the UV-irradiance was the most significant factor that affected the color change in both Scots pine and poplar wood (Table 6). The UV-irradiance had a $39.45 \%$ effect on the color change in the Scots pine wood and a $28.51 \%$ effect on the poplar wood. However, the error frequencies were quite high for both tree species. The rows which are marked as "Error" refer to the error caused by uncontrollable factors (noise). In the literature, it is stated that this value should be below $50 \%$ for the results to be reliable (Pourjafar et al. 2013). The error value was below 50\% for both specimens.

Table 6. ANOVA Results for Scots Pine and Poplar Wood

\begin{tabular}{|c|c|c|c|c|c|c|c|}
\hline \multirow[t]{2}{*}{ Parameters } & Codes & DF & $\begin{array}{c}\text { Sum of } \\
\text { Squares } \\
\text { (SS) }\end{array}$ & $\begin{array}{r}\text { Mean of } \\
\text { Squares } \\
\text { (MS) }\end{array}$ & F-Value & $\begin{array}{c}\text { Contribution } \\
\text { Rate }\end{array}$ & Rank \\
\hline & \multicolumn{7}{|c|}{ Scots pine } \\
\hline Direction & $A$ & 1 & 0.0252 & 0.0252 & 0.01 & 0.03 & 4 \\
\hline UV-irradiance $\left(\mathrm{W} / \mathrm{m}^{2}\right)$ & B & 2 & 35.7220 & 17.8610 & 4.70 & 39.45 & 1 \\
\hline Conditioning $(\mathrm{h})$ & C & 2 & 2.7600 & 1.3800 & 0.36 & 3.05 & 3 \\
\hline Water (min) & $\mathrm{D}$ & 2 & 14.0381 & 7.0190 & 1.85 & 15.50 & 2 \\
\hline Error (\%) & - & 10 & 38.0126 & 3.8013 & - & 41.98 & - \\
\hline \multirow[t]{2}{*}{ Total } & - & 17 & 90.5579 & - & - & 100 & - \\
\hline & \multicolumn{7}{|c|}{ Poplar } \\
\hline Direction & A & 1 & 2.669 & 2.669 & 0.92 & 3.34 & 4 \\
\hline $\begin{array}{c}\text { UV-irradiance } \\
\left(\mathrm{W} / \mathrm{m}^{2}\right)\end{array}$ & B & 2 & 22.775 & 11.388 & 3.93 & 28.51 & 1 \\
\hline Conditioning (h) & $\mathrm{C}$ & 2 & 10.894 & 5.447 & 1.88 & 13.64 & 3 \\
\hline Water (min) & $\mathrm{D}$ & 2 & 14.590 & 7.295 & 2.52 & 18.26 & 2 \\
\hline Error (\%) & - & 10 & 28.966 & 2.897 & - & 36.26 & - \\
\hline Total & - & 17 & 79.894 & - & - & 100 & - \\
\hline
\end{tabular}


Regression models were established to estimate the color change parameters of Scots pine and poplar wood. These models are provided in Eq. 3 and Eq. 4.

$$
\begin{gathered}
\Delta E_{\text {scotspine }}=14.816+0.037 D_{\text {radial }}-0.037 D_{\text {tangential }}+1.879 U V_{0.50}- \\
1.513 U V_{0.75}-0.367 U V_{1.00}-0.481 C_{2}+0.002 C_{4}+0.478 C_{6}+ \\
1.005 W_{15}+1.145 W_{30}+0.140 W_{45}
\end{gathered}
$$

$$
\begin{gathered}
\Delta E_{\text {poplar }}=17.479-0.385 D_{\text {radial }}+0.385 D_{\text {tangential }}+0.322 U V_{0.50}- \\
1.510 U V \quad 0.75+1.188 U V{ }_{1.00}+1.075 C_{2}-0.334 C_{4}- \\
0.741 C_{6}+1.262 W_{15}-0.777 W_{30}-0.485 W_{45}
\end{gathered}
$$

Here, the color change $(\Delta E)$ is a dependent variable, whereas direction (D), UVirradiance (UV), conditioning (C), and water (W) are independent variables. The $\mathrm{R}^{2}$ value of this model was $58.02 \%$ for Scots pine and $63.74 \%$ for poplar wood. These values are acceptable for estimation. The correlation coefficient $(\mathrm{R})$ for Scots pine was 0.76 and 0.80 for poplar, which showed the relationship between the variables to be linear and above the accepted limits of 0.60 to 0.70 outlined in the literature (Cabuk et al. 2011; Kurt et al. 2016).

There have been many studies on the changes on wood material caused by outdoor weather conditions. UV radiance creates free radicals on the wood surface; these free radicals produce hydrogen peroxide, which is easily broken down by the effect of oxygen and water (Feist and Hon 1984). These free radicals cause the degradation of lignin and the photooxidation of these structures by breaking down the chains of cellulose and hemicelluloses (Pandey 2005).

\section{CONCLUSIONS}

In this study, the effect of accelerated weathering factors on the total color change of the wood surfaces of Scots pine (Pinus sylvestris L.) and poplar (Populus $x$ euroamericana) were investigated. Four parameters thought to be effective on the color change were optimized using the $\mathrm{L}_{18}$ Taguchi orthogonal array. The experimental results were then evaluated via ANOVA analysis.

1. In both tree species, a minimum total color change was obtained with a process of 0.75 $\mathrm{W} / \mathrm{m}^{2} \mathrm{UV}$-irradiance and $30 \mathrm{~min}$ of water spraying. The use of different tree species led to different behaviors in the specimens against the factors of accelerated weathering. The minimum total color change values were achieved on the tangential surfaces in the Scots pine specimens and on the radial surfaces in the poplar specimens. The ANOVA analysis showed the UV-irradiance to be the most effective factor on the total color change.

2. All results showed that the Taguchi method was generally very effective both in decreasing the number of experiments and in determining the optimum parameters that affected color change. In addition, this demonstrates that the Taguchi method could be used to optimize and forecast processes to determine the best results from other combinations that were not tested. 
3. There are a great number of parameters that affect color change in wood. In particular, this was thought to be the origin of the high error value (attributed to "uncontrollable factors") obtained in the ANOVA results in this study. Therefore, in future studies it is believed that better results could be obtained by including different parameters which might affect color change in the model.

\section{REFERENCES CITED}

Apparao, K. C., and Birru, A. K. (2017). "Optimization of die casting process based on Taguchi approach,” Materials Today: Proceedings 4(2), 1852-1859. DOI: 10.1016/j.matpr.2017.02.029

ASTM G154-16. (2016). "Standard practice for operating fluorescent ultraviolet (UV) lamp apparatus for exposure of nonmetallic materials," American Society for Testing and Materials, West Conshohocken, PA.

Balki, M. K., Sayin, C., and Sarıkaya, M. (2016). "Optimization of the operating parameters based on Taguchi method in an SI engine used pure gasoline, ethanol and methanol," Fuel 180(15), 630-637. DOI: 10.1016/j.fuel.2016.04.098

Baysal, E., Tomak, E.D., Ozbey, M., Altin, E. (2014). "Surface properties of impregnated and varnished Scots pine wood after accelerated weathering". Coloration Technology, 130 (2): 140-146. DOI: 10.1111/cote. 12070

Bose, P. K., Deb, M., Banerjee, R., and Majumder, A. (2013). "Multi objective optimization of performance parameters of a single cylinder diesel engine running with hydrogen using a Taguchi-fuzzy based approach," Energy 63, 375-386. DOI: 10.1016/j.energy.2013.10.045

Cabuk, Y., Karayilmazlar, S., Aytekin, A., and Kurt, R. (2011). "Statistical analysis and projection of wood veneer industry in Turkey: 2007-2021," Scientific Research and Essays 6(15), 3205-3216.

Can, A., and Sivrikaya, H. (2019). "Surface characterization of wood treated with boron compounds combined with water repellents," Color Research and Application 44(3), 462-472. DOI: $10.1002 / \mathrm{col} .22357$

Chamoli, S. A. (2015). "Taguchi approach for optimization of flow and geometrical parameters in a rectangular channel roughened with V down perforated baffles," Case Studies in Thermal Engineering 5, 59-69. DOI: 10.1016/j.csite.2015.01.001

Chen, D.-C., Lin, J.-Y., Jheng, M.-W., and Chen, J.-M. (2007). "Design of titanium alloy superplastic blow-forming in ellip-cylindrical die using Taguchi method," in: Proceedings of the $35^{\text {th }}$ International MATADOR Conference, Springer, London, pp. 105-109.

Chiang, Y. M., and Hsieh, H. H. (2009). "The use of the Taguchi method with grey relational analysis to optimize the thin-film sputtering process with multiple quality characteristic in color filter manufacturing," Computers \& Industrial Engineering 56(2), 648-661. DOI: 10.1016/j.cie.2007.12.020

Feist, W. C. (1990). "Weathering performance of painting wood pretreated with waterrepellent preservatives," Forest Products Journal 40(7/8), 21-26.

Feist, W. C., and Hon, D. N.-S. (1984). "Chemistry of weathering and protection," in: The Chemistry of Solid Wood, R. Rowell (ed.), American Chemical Society, Seattle, WA, pp. 401-451.

Günay, M., and Yücel, E. (2013). “Application of Taguchi method for determining 
optimum surface roughness in turning of high-alloy white cast iron," Measurement 46(2), 913-919. DOI: 10.1016/j.measurement.2012.10.013

Günay, M., Kaçal, A., and Turgut, Y. (2011). "Optimization of machining parameters in milling of Ti-6Al-4V alloy using Taguchi method," e-Journal of New World Sciences Academy 6(1), 428-440. DOI: 10.12739/NWSAES.V6I1.5000067046

ISO 554 (2016). "Standard atmospheres for conditioning and/or testing-Specifications" International Organization for Standardization, Geneva, Switzerland

ISO 7724-2 (1984). "Paints and varnishes-Colorimetry-Part 2: Colour measurement," International Organization for Standardization, Geneva, Switzerland

Joshaghani, A., Ramezanianpour, A. A., Ataei, O., and Golroo, A. (2015). “Optimizing pervious concrete pavement mixture design by using the Taguchi method," Construction and Building Materials 101(1), 317-325. DOI: 10.1016/j.conbuildmat.2015.10.094

Kivak, T. (2014). "Optimization of surface roughness and flank wear using the Taguchi method in milling of Hadfield steel with PVD and CVD coated inserts," Measurement 50, 19-28. DOI: 10.1016/j.measurement.2013.12.017

Kropat, M., Hubbe, M. A., and Laleicke, F. (2020). "Natural, accelerated, and simulated weathering of wood: A review," BioResources, 15(4), 9998-10062.

Kurt, M., Bagci, E., and Kaynak, Y. (2009). “Application of Taguchi methods in the optimization of cutting parameters for surface finish and hole diameter accuracy in dry drilling progress," The International Journal of Advanced Manufacturing Technology 40, 458-469. DOI: 10.1007/s00170-007-1368-2

Kurt, R., Karayilmazlar, S., and Cabuk, Y. (2016). "Important non-wood forest products in Turkey: An econometric analysis," Engineering, Technology and Applied Science Research 6(6), 1245-1248.

Mandal, N., Doloi, B., Mondal, B., and Das, R. (2011). "Optimization of flank wear using Zirconia Toughened Alumina (ZTA) cutting tool: Taguchi method and regression analysis," Measurement 44(10), 2149-2155. DOI: 10.1016/j.measurement.2011.07.022

Mezarcioz, S., and Ogulata, R. T. (2010). "Optimization of bursting strength of single jersey fabrics with Taguchi orthogonal design," Tekstil ve Konfeksiyon 20(4), 320328.

Naik, A. B., and Reddy, A. C. (2018). "Optimization of tensile strength in TIG welding using the Taguchi method and analysis of variance (ANOVA)". Thermal Science and Engineering Progress 8, 327-339. DOI: 10.1016/j.tsep.2018.08.005

Özgenç, Ö. (2014). Increasing Resistance of Wooden Materials Used in Mountain Houses of Eastern Black Sea Region to Weather Conditions, Ph.D. Dissertation, Karadeniz Technical University, Trabzon, Turkey.

Pandey, K.K. (2005). "A note on the influence of extractives on the photo-discoloration and photo-degradation of wood," Polmer Degradation and Stability 87, 375-379. DOI: 10.1016/j.polymdegradstab.2004.09.007

Pourjafar, S., Jahanshahi, M., and Rahimpour, A. (2013). "Optimization of $\mathrm{TiO}_{2}$ modified poly(vinyl alcohol) thin film composite nanofiltration membranes using Taguchi method," Desalination 315, 107-114. DOI: 10.1016/j.desal.2012.08.029

Ross, P. J. (1988). Taguchi Techniques for Quality Engineering: Loss Function, Orthogonal Experiments, Parameter and Tolerance Design, McGraw-Hill, New York, NY.

Sarikaya, M., and Güllü, A. (2015). "Multi-response optimization of minimum quantity 
lubrication parameters using Taguchi-based grey relational analysis in turning of difficult-to-cut alloy Haynes-25," Journal of Cleaner Production 91, 347-357. DOI: j.jclepro.2014.12.020

Taguchi, G., Chowdhury, S., and Wu, Y. (2005). Taguchi's Quality Engineering Handbook, John Wiley \& Sons, Inc., Hoboken, NJ.

Temiz, A. (2005). The Effect of Simulated Weathering on Preservative Treated Wood, Ph.D. Dissertation, Karadeniz Technical University, Trabzon, Turkey.

Temiz, A., Terziev, N., Eikenes, M., and Hafren, J. (2007). "Effect of accelerated weathering on surface chemistry of modified wood," Applied Surface Science 253(12), 5355-5362. DOI: 10.1016/j.apsusc.2006.12.005

Temiz, A., Yildiz, U. C., Aydin, I., Eikenes, M., Alfredsen, G., and Çolakoglu, G. (2005). "Surface roughness and color characteristics of wood treated with preservatives after accelerated weathering test," Applied Surface Science 250(1-4), 35-42. DOI: 10.1016/j.apsusc.2004.12.019

Tian, S., Luo, Y., Chen, J., He, H., Chen, Y., and Ling, Z. (2019). "A comprehensive study on the accelerated weathering properties of polypropylene-wood composites with non-metallic materials of waste-printed circuit board powders," Materials 12(6), 876. DOI: $10.3390 / \mathrm{ma} 12060876$

Turkoglu, T., Baysal, E., Toker, H. (2015). "The effects of natural weathering on color stability of impregnated and varnished wood materials," Advances in Materials Science and Engineering 2015(4), 1-9. DOI: 10.1155/2015/526570

Way, D., Kamke, F. A., and Sinha, A. (2018). "Influence of specimen size during accelerated weathering of wood-based structural panels," Wood Material Science \& Engineering 15(1), 1-13. DOI: 10.1080/17480272.2018.1459836

Williams, R., S., Knaebe, P., Sotos, P. G., and Feist, W. C. (2001). "Erosion rates of wood during natural weathering. Part II. Earlywood and Latewood Erosion Rates," Wood and Fiber Science 33, 1, 43-49.

Article submitted: August 12, 2020; Peer review completed: October 4, 2020; Revised version received and accepted: December 16, 2020; Published: January 19, 2021.

DOI: 10.15376/biores.16.1.1642-1653 